\title{
ERRATUM
}

C. Lohmann · G. Eggers-Schumacher · M. Wunderlich

F. Schöffl

\section{Two different heat shock transcription factors regulate immediate early expression of stress genes in Arabidopsis}

Published online: 13 March 2004

(C) Springer-Verlag 2004

\section{Mol Genet Genomics (2004) 271:11-21}

This paper was communicated by R. Hagemann, not by G. Jürgens. 